\title{
TREATMENT OF TANNERY EFFLUENT BY COAGULATION
}

\author{
Shaheen Fathima A \\ PG scholar \\ Department of Environmental \\ Engineering \\ Government College of technology, \\ Coimbatore, Tamilnadu, India
}

\author{
Bhuvaneswari R \\ Asst.Proffessor \\ Department of Environmental \\ Engineering \\ Government College of technology, \\ Coimbatore, Tamilnadu, India
}

\author{
Jeyanthi J \\ Head of the Department \\ Department of Environmental \\ Engineering \\ Government College of technology \\ Coimbatore, Tamilnadu, India
}

\begin{abstract}
Tannery is associate oldest and quickest growing business in Asian country. Virtually each Tannery industry uses important amounts of chemicals within the method of reworking animal hides into animal skin. Those chemicals discharged through Tannery industrial effluent ends up in pollution. Therefore this project puts forth the characterization and treatment of tannery effluent by synthesizing aloevera leaf as a natural coagulant. The analysis results show that the effluents possess very high values of turbidity, hardness, chlorides, TSS, Total solids, TDS, and COD. Those values were way on top of the quality permissible limits set by the Central Pollution panel (CPCB). Thus it's necessary to treat the tannery industrial effluent for safe disposal. This study targeted on the coagulation - flocculation process that is one in all the foremost chemical science treatment steps utilized in Tannery industrial waste treatment to scale back suspended and mixture materials. The take a look at were dole out victimization tannery industrial waste with typical jar test equipment. This study conjointly conducted the improvement of varied method parameters like $\mathrm{pH}$ scale, coagulant dose and make contact with time. It had been found that the proportion of reduction at high for the best dose of concerning $1.5 \mathrm{~g} / \mathrm{l}$, that shows reduction potency of physico-chemical parameters like turbidity, Chlorides, Hardness, TSS, TS and TDS. The potency removal were concerning $86 \%, 87 \%, 88 \%$ for turbidness, TDS, TS and syndrome whereas the removal potency of Chlorides and Hardness was found to be $75 \%$ and $77 \%$ severally.
\end{abstract}

Keywords: Tannery effluent, Aloevera, Coagulation process, Natural coagulant

\section{INTRODUCTION}

The Tannery Industry in worldwide not solely represents economic process, however is additionally a supply of contaminants that area unit polluting rivers and groundwater. Nearly every Tannery Industry uses vital quantity of chemicals within the strategy of transforming animal hides into animal product. Regarding ninetieth of
Tannery industries area unit engaged within the chrome tanning technique as a results of it's simple operational and renders howling properties to the animal skin. The Tannery effluent damages the standard amount of the receiving water bodies and land surface. Generally, water consumption within the soaking stage of the tanning technique, contributes around $50-55 \%$ of the total pollution load of the tanning Industry. Inside the liming stage, protein, hair, skin and intermingled fats area unit far away from the hides, then unit discharged within the effluent and increase its total solids contents. The effluents from the de-liming and bating contain sulphides, ammonia salts, and metallic element salts, and thus the effluent is slightly alcalescent. The pickling and chrome tanning effluents contain vitriol, chrome, chlorides, hydrogen carbonate of soda and sulphates. Alone regarding two hundredth of huge sort of chemicals utilized in the tanning technique is absorbed by animal product and therefore the rest is discharged as wastes the foremost pollutants of the posttanning technique area unit chrome salts, colouring material residues, fat liquoring coagulants and different organic matter. Though tanneries unit of measurement revenue and job providing sector, the pollution from their effluent is of major concern. All the pollutants, likewise as serious metals, cause serious health hazards as a result of unsafe disposal of untreated effluents on soil and water. Human health could also be affected by harmful hazards cause through the unskilled and unsafe handling of pesticides, tanning chemicals, and treated hides and skins. Therefore, it's necessary to treat the Tannery effluent for safe disposal whereas not inflicting harmful effects to person and setting. However, the utilization of those chemical coagulants resulted in many downsides like harmful voluminous sludge production. There also are coagulants derived from plant-based materials mentioned as natural coagulant. Natural coagulants area unit safe and ecofriendly. Sessou Philippe et al (2016) showed that the aloevera used as an alternative to chemical flocculants for the treatment of turbid water. This study reveals that the synthesized aloevera powder as a natural coagulant utilized in treatment of Tannery Industrial effluent to look at the potency of coagulation process in terms of the removal of muddiness, TS, 
TDS, TSS, Chlorides and Hardness to predict the optimum indefinite quantity of coagulant.

\section{MATERIALS AND METHODS}

In this study, The Tannery industrial effluent sample was collected from one among the leading Tannery Industry at Erode district. The sample was collected throughout the month of September wherever the corporate was in traditional production. The sample were collected from discharging effluents of chrome tanning in Tannery Industry. The collected samples were then hold on at cold storage to stop the decomposition of sample which can lead to errors throughout characterization of effluent. The sample is then analyzed for various physico chemical parameters

\section{A. Synthesis of natural coagulant}

An Aloe plant leaves was taken as a natural coagulant for the treatment of Tannery effluent. Associate succulent leaves were collected from the regionally accessible study space. It's then sliced into various items and unbroken those succulent leaves items to sun dried for 5 days, so as to get rid of the presence of wetness content. Then those dried succulent leaves were fine-grained in ball mill for twelve hours at 240 rpm. The finally obtained fine grained powder unbroken in associate air tight instrumentation and used as a natural coagulant.

\section{B. Coagulant studies}

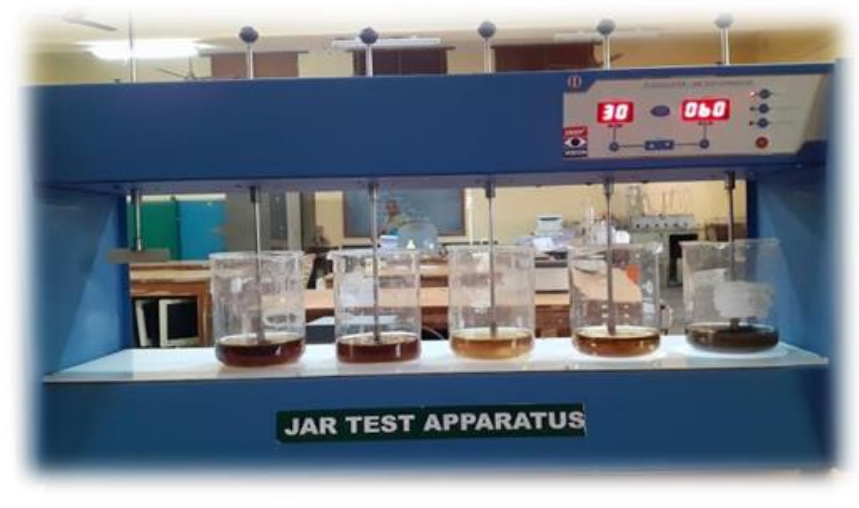

Fig. 1. JAR test Apparatus

Fig. 1. The jar take a look at equipment was filled with sample water. One in every of the instrumentation used as an impression whereas the opposite five containers adjusted reckoning on what conditions area unit being tested. For instance, the hydrogen ion concentration of the jars were adjusted or variations of coagulant dosages supplementary to Tannery out optimum operative conditions. The coagulant dosages to every instrumentation area unit supplementary and stirred at more or less one hundred revolutions for one minute. The speedy combine stage helps to disperse the coagulant throughout every instrumentation. The paddles were turned off and allowed the containers to accept thirty to forty five minutes. Then the ultimate muddiness in every instrumentation were measured. The stirring speed was reduced to twenty five to thirty five revolutions and there exist continuous commixture for fifteen to twenty minutes. This slower commixture speed helps promote floccule formation by enhancing particle collisions that result in larger flocs.Residual muddiness vs. coagulant dose is then planned and best conditions area unit determined. The values that area unit obtained through the experiment area unit related and adjusted so as to account for the particular treatment system.The same process distributed to predict the optimisation of method parameters like coagulant indefinite quantity, hydrogen ion concentration and contact time for exploitation of aloevera.

\section{RESUlT AND DISCUSSION}

This study shows the characterization and treatment of tannery industry effluent was carried out using Aloevera leaves as a natural coagulant. Manjushree Chowdhury et al (2015) has showed the values of physico chemical parameters in tannery effluent. The values for physico-chemical characteristics of tannery effluent and the results of coagulation studies obtained were shown in both tabular and graphical form below

\section{A. Physico-chemical characteristics of tannery effluent}

Table -1 Characterization of tannery effluent

\begin{tabular}{|l|l|}
\hline $\mathrm{pH}$ & 6.3 \\
\hline Turbidity & $650 \mathrm{NTU}$ \\
\hline Total solids & $16550 \mathrm{mg} / \mathrm{l}$ \\
\hline $\mathrm{TDS}$ & $8000 \mathrm{mg} / \mathrm{l}$ \\
\hline BOD & $2550 \mathrm{mg} / \mathrm{l}$ \\
\hline COD & $60400 \mathrm{mg} / 1$ \\
\hline Total Hardness & $2500 \mathrm{mg} / 1$ \\
\hline Chlorides & $18848 \mathrm{mg} / \mathrm{l}$ \\
\hline Total Suspended Solids & $8550 \mathrm{mg} / 1$ \\
\hline Colour & light brown \\
\hline
\end{tabular}

\section{$B$. Coagulation studies}

An Aloevera is synthesized as a natural coagulant. Saravanan J et al (2017) has analyzed the important parameters of coagulation such as $\mathrm{pH}$, coagulant dosage and contact time. The responses taken into consideration are Turbidity, TS, TDS, TSS, Chlorides and Hardness removal. A 
conventional jar test apparatus was used to optimize the process parameters. Fersi C et al (2018) explained that the coagulation process using natural coagulant seems to be good pretreatment method for tannery effluent. The results obtained were shown in both tabular and graphical form below.

Effect of coagulant dosage on turbidity removal using aloevera

Ranging the coagulant dosage from 0.5 to $2.5 \mathrm{~g} / \mathrm{l}$ at a constant contact time of 30 mins, various percentage of turbidity removal were observed from the table 2 and fig 2 . But the max turbidity removal was achieved by $1.5 \mathrm{~g} / \mathrm{l}$ of coagulant dosage.

Table-2 Effect of coagulant dosage on Turbidity removal using

\begin{tabular}{|c|c|c|}
\hline $\begin{array}{c}\text { Coagulant } \\
\text { Dosage (g/l) }\end{array}$ & $\begin{array}{c}\text { Contact Time } \\
\text { (Min) }\end{array}$ & $\begin{array}{c}\text { \% Removal Of } \\
\text { Turbidity }\end{array}$ \\
\hline 0.5 & 30 & $\mathbf{8 4 . 3 2}$ \\
\hline 1 & 30 & 85.82 \\
\hline 1.5 & 30 & 87 \\
\hline 2 & 30 & 86.86 \\
\hline 2.5 & 30 & 86.56 \\
\hline
\end{tabular}

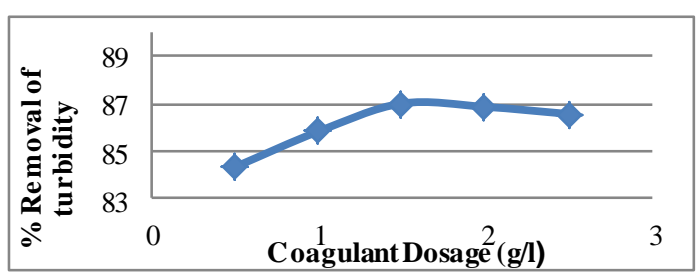

Fig. 2. Effect of coagulant dosage on Turbidity removal using Aloevera

Effect of coagulant dosage on Total Solids, Total Suspended Solids \& Total Dissolved Solids removal using aloevera

Varying the coagulant dosage from 0.5 to $2.5 \mathrm{~g} / \mathrm{l}$ In a constant contact time of about 30 mins. The removal of TS, TDS, TSS were observed from the table 3 and fig 3 . It can be seen that the maximum removal of TS, TDS, TSS obtained at $1.5 \mathrm{~g} / \mathrm{l}$ of coagulant dosage

Table-3. Effect of Coagulant Dosage on TS, TSS and TDS Removal Using Aloevera.

\begin{tabular}{|c|c|c|c|c|}
\hline $\begin{array}{c}\text { Coagulant } \\
\text { Dosage } \\
(\mathrm{g} / \mathrm{l})\end{array}$ & $\begin{array}{c}\text { Contact } \\
\text { Time } \\
\text { (Min) }\end{array}$ & $\begin{array}{c}\text { \% } \\
\text { Removal } \\
\text { of TS }\end{array}$ & $\begin{array}{c}\% \\
\text { Removal } \\
\text { of TDS }\end{array}$ & $\begin{array}{c}\% \\
\text { Removal } \\
\text { of TSS }\end{array}$ \\
\hline 0.5 & 30 & 76.20 & 75 & 77.48 \\
\hline 1 & 30 & 81.99 & 81.25 & 82.78 \\
\hline 1.5 & 30 & 87.13 & 86.25 & 88.07 \\
\hline 2 & 30 & 85.85 & 84.37 & 87.41 \\
\hline 2.5 & 30 & 86.41 & 85 & 87.07 \\
\hline
\end{tabular}

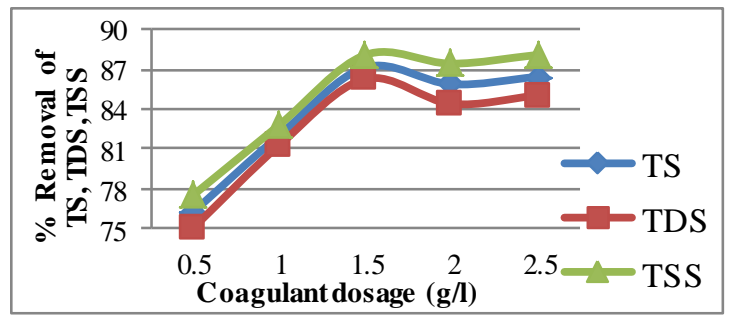

Fig. 3. Effect of Coagulant Dosage on TS, TSS and TDS Removal Using Aloevera.

Effect of Coagulant Dosage on Chlorides And Hardness Removal Using Aloevera

At a constant contact time of 30 mins, By fluctuating the coagulant dosage from 0.5 to $2.5 \mathrm{~g} / \mathrm{l}$. The removal of chlorides and hardness were obtained at the optimum dosage of $1.5 \mathrm{~g} / \mathrm{l}$ using Table 4 and fig 4 .

Table-4. Effect of coagulant dosage on chlorides and hardness removal using aloevera

\begin{tabular}{|c|c|c|c|}
\hline $\begin{array}{c}\text { Coagulant } \\
\text { Dosage (g/l) }\end{array}$ & $\begin{array}{c}\text { Contact } \\
\text { Time (Min) }\end{array}$ & $\begin{array}{c}\text { \% Removal of } \\
\text { Chloride }\end{array}$ & $\begin{array}{c}\text { \% Removal of } \\
\text { Hardness }\end{array}$ \\
\hline 0.5 & 30 & 68.82 & 65.15 \\
\hline 1 & 30 & 70.26 & 69.30 \\
\hline 1.5 & 30 & 75.00 & 77.00 \\
\hline 2 & 30 & 73.13 & 72.30 \\
\hline 2.5 & 30 & 72.17 & 71.59 \\
\hline
\end{tabular}

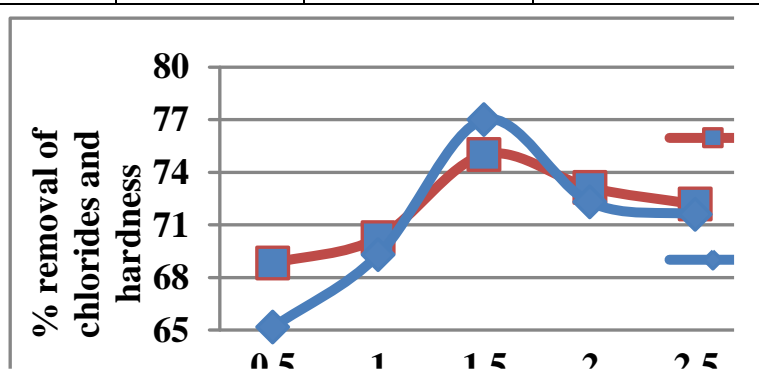

Fig. 4. Effect of coagulant dosage on chlorides and hardness removal using aloevera

\section{Effect of pH on Turbidity Removal Using Aloevera}

Ranging the $\mathrm{pH}$ from 2 to 10 at a constant coagulant dosage and contact time various percentage of turbidity removal were observed from the table 5 and fig 5 . But the maximum turbidity removal was achieved by $\mathrm{pH}-4$

Table-5. Effect of $\mathrm{pH}$ on turbidity removal using aloevera

\begin{tabular}{|c|c|c|c|}
\hline pH & $\begin{array}{c}\text { Coagulant } \\
\text { Dosage (g/l) }\end{array}$ & $\begin{array}{c}\text { Contact Time } \\
\text { (Min) }\end{array}$ & $\begin{array}{c}\text { Percentage Removal } \\
\text { Of Turbidity }\end{array}$ \\
\hline 2 & 1.5 & 30 & 80.25 \\
\hline 4 & 1.5 & 30 & 82.36 \\
\hline 6 & 1.5 & 30 & 78.50 \\
\hline 8 & 1.5 & 30 & 65.15 \\
\hline 10 & 1.5 & 30 & 63.53 \\
\hline
\end{tabular}




\begin{tabular}{|c|c|c|c|c|}
\hline pH & $\begin{array}{c}\text { Coagulant } \\
\text { Dosage (g/l) }\end{array}$ & $\begin{array}{c}\text { Contact } \\
\text { Time (Min) }\end{array}$ & $\begin{array}{c}\text { \% Removal } \\
\text { of Chlorides }\end{array}$ & $\begin{array}{c}\text { \% Removal } \\
\text { of Hardness }\end{array}$ \\
\hline 2 & 1.5 & 30 & 65.79 & 72.26 \\
\hline 4 & 1.5 & 30 & 70.56 & 76.93 \\
\hline 6 & 1.5 & 30 & 68.38 & 70.56 \\
\hline 8 & 1.5 & 30 & 62.82 & 67.13 \\
\hline 10 & 1.5 & 30 & 57.45 & 64.35 \\
\hline
\end{tabular}

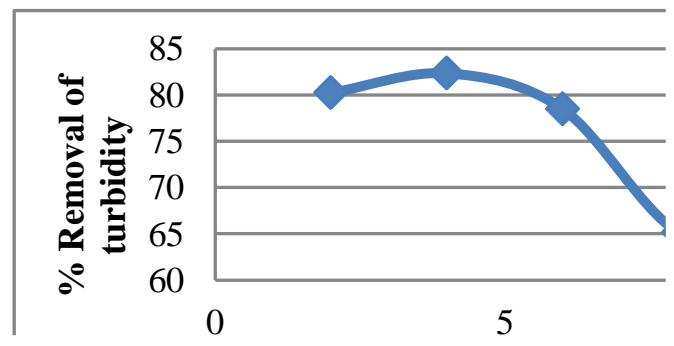

Fig. 5. Effect of $\mathrm{pH}$ on turbidity removal using aloevera

Effect of pH on Total Solids, Total Suspended Solids \& Total Dissolved Solids Removal Using Aloevera

\begin{tabular}{|c|c|c|c|c|c|}
\hline $\mathrm{pH}$ & $\begin{array}{l}\mathrm{CD} \\
(\mathrm{g} / \mathrm{l})\end{array}$ & $\begin{array}{l}\mathrm{CT} \\
\text { (Min) }\end{array}$ & $\begin{array}{l}\text { \% Remov } \\
\text { al of TS }\end{array}$ & $\begin{array}{l}\text { \% Removal } \\
\text { of TDS }\end{array}$ & $\begin{array}{l}\text { \% Remov } \\
\text { al of TSS }\end{array}$ \\
\hline 2 & 1.5 & 30 & 65.35 & 60.48 & 70.63 \\
\hline 4 & 1.5 & 30 & 75.23 & 72.35 & 78.54 \\
\hline 6 & 1.5 & 30 & 63.40 & 66.67 & 56.33 \\
\hline 8 & 1.5 & 30 & 58.89 & 53.54 & 51.27 \\
\hline 10 & 1.5 & 30 & 56.16 & 40.97 & 48.70 \\
\hline
\end{tabular}

Varying the $\mathrm{pH}$ from 2 to 10 in a constant contact time of about 30 mins and coagulant dosage of $1.5 \mathrm{~g} / \mathrm{l}$. The removal of TS, TDS and TSS were observed from the table 6 and fig 6. It can be seen that the maximum removal of TS, TDS and TSS obtained at $\mathrm{pH}-4$

Table-6. Effect of pH on TS, TDS, TSS removal using aloevera

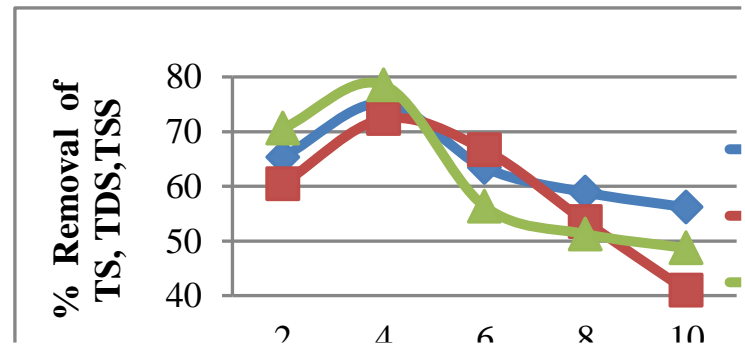

Fig. 6. Effect of $\mathrm{pH}$ on TS, TDS, TSS removal using aloevera

\section{Effect of pH on Chlorides and Hardness Removal Using Aloevera}

At a constant contact time of 30 mins and $1.5 \mathrm{~g} / \mathrm{l}$ of coagulant dosage. By fluctuating the $\mathrm{pH}$ from 2 to 10 . The maximum removal of chlorides and hardness were obtained at $\mathrm{pH} 4$ is shown in the table 7 and fig 7.
Table-7. Effect of pH on chlorides and hardness removal using aloevera

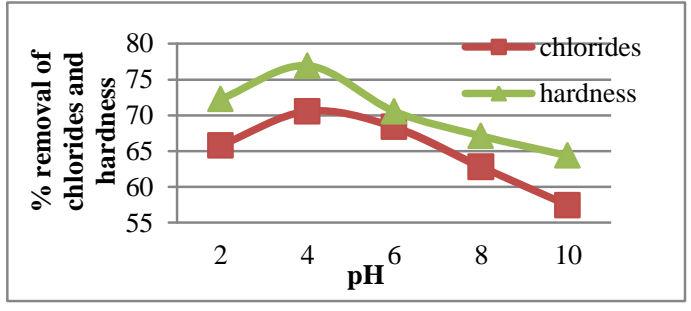

Fig. 7. Effect of $\mathrm{pH}$ on chlorides and hardness removal

\section{Effect Of Contact Time On Turbidity Removal Using Aloevera}

Contact time also play an important role in removal of turbidity. From the table 8 and fig 8 It is observed that $88 \%$ of turbidity can be removed at the contact time of about 30mins.

Table-8. Effect of contact time on turbidity removal using aloevera

\begin{tabular}{|c|c|c|c|}
\hline $\mathbf{p H}$ & $\begin{array}{c}\text { Coagulant } \\
\text { Dosage (g/l) }\end{array}$ & $\begin{array}{c}\text { Contact } \\
\text { Time (Min) }\end{array}$ & $\begin{array}{c}\text { \% Removal of } \\
\text { Turbidity }\end{array}$ \\
\hline & 1.5 & 10 & 60.29 \\
\hline 4 & 1.5 & 20 & 75.23 \\
\hline 4 & 1.5 & 30 & 87.65 \\
\hline 4 & 1.5 & 40 & $\mathbf{8 0 . 3 5}$ \\
\hline 4 & 1.5 & 50 & 74.94 \\
\hline
\end{tabular}

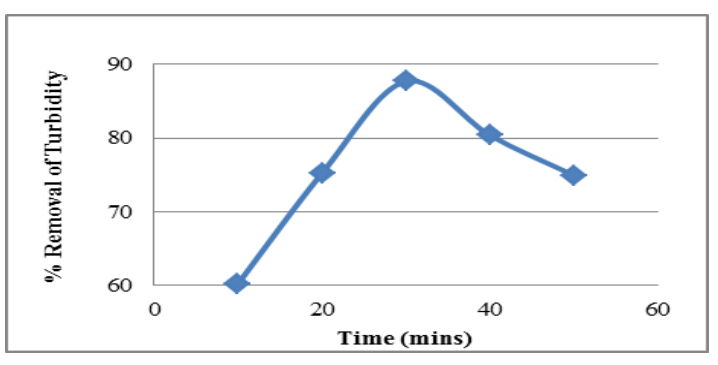

Fig. 8.Effect of contact time on turbidity removal using aloevera

\section{Effect of Contact Time on TS, TSS, TDS Removal Using Aloevera}

At a constant coagulant dosage of $1.5 \mathrm{~g} / \mathrm{l}$ and $\mathrm{pH}$ of about 4 . By varying the contact time 10 to 50 mins. From the table 9 and fig 9 The percentage removal of TS, TSS and TDS were observed.

Table-9. Effect of contact time on ts, tss, tds removal using aloevera

\begin{tabular}{|c|c|c|c|c|c|}
\hline pH & $\begin{array}{c}\text { Coagulant } \\
\text { Dosage } \\
(\mathrm{g} / \mathrm{l})\end{array}$ & $\begin{array}{c}\text { Contact } \\
\text { Time } \\
\text { (Min) }\end{array}$ & $\begin{array}{l}\% \\
\text { Removal } \\
\text { of TS }\end{array}$ & $\begin{array}{c}\% \\
\text { Removal } \\
\text { of TSS }\end{array}$ & $\begin{array}{c}\% \\
\text { Removal } \\
\text { of TDS }\end{array}$ \\
\hline 4 & 1.5 & 10 & 79.5 & 75.19 & $\mathbf{7 6 . 3 2}$ \\
\hline 4 & 1.5 & 20 & $\mathbf{8 0 . 1 2}$ & $\mathbf{7 8 . 2 1}$ & $\mathbf{8 1 . 4 6}$ \\
\hline 4 & 1.5 & 30 & $\mathbf{8 9 . 9 1}$ & $\mathbf{8 5 . 3 3}$ & $\mathbf{8 7 . 9 3}$ \\
\hline
\end{tabular}




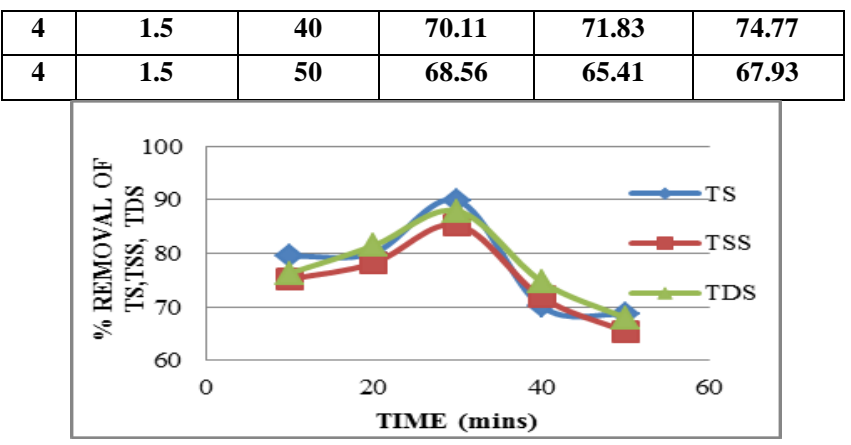

Fig. 9. Effect of contact time on TS, TSS, TDS removal using aloevera

Effect of Contact Time on Chlorides and Hardness Removal Using Aloevera

At a constant coagulant dosage of $1.5 \mathrm{~g} / \mathrm{l}$ and $\mathrm{pH}$ of about 4. Ranging the contact time of coagulation 10 to 50 mins. From the table 4.10 and fig 4.14. The percentage removal of Chlorides and Hardness were observed.

Table-10. Effect of contact time on chlorides and hardness removal using aloevera

\begin{tabular}{|c|c|c|c|c|}
\hline pH & $\begin{array}{c}\text { Coagulant } \\
\text { Dosage } \\
(\mathrm{g} / \mathrm{l})\end{array}$ & $\begin{array}{c}\text { Contact } \\
\text { Time } \\
(\text { Min })\end{array}$ & $\begin{array}{l}\text { \%Removal of } \\
\text { Chlorides }\end{array}$ & $\begin{array}{c}\text { \% Removal of } \\
\text { Hardness }\end{array}$ \\
\hline 4 & 1.5 & 10 & 75.65 & 77.24 \\
\hline 4 & 1.5 & 20 & 79.34 & 81.91 \\
\hline 4 & 1.5 & 30 & 90.11 & 88.46 \\
\hline 4 & 1.5 & 40 & 82.33 & 75.59 \\
\hline 4 & 1.5 & 50 & 78.62 & 71.73 \\
\hline
\end{tabular}

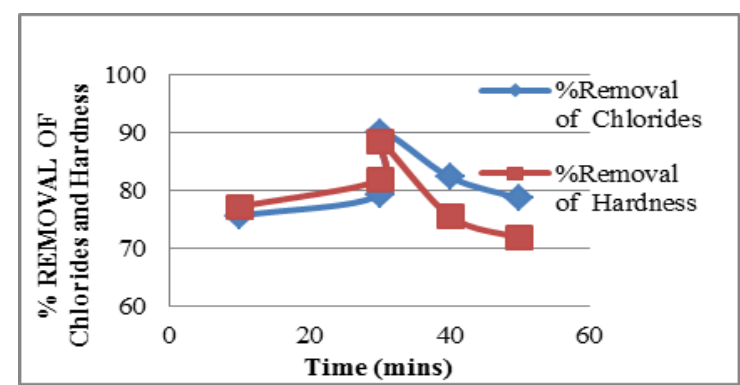

Fig. 10. Effect of contact time on chlorides and hardness removal using aloevera

\section{CONCLUSION}

The present study demonstrates the characterization of tannery effluent and synthesis of aloevera as a natural coagulant. From the characteristic study, the obtained values for parameters such as hardness is $2600 \mathrm{mg} / \mathrm{l}$, turbidity is 670 NTU, chlorides is $20848 \mathrm{mg} / \mathrm{l}$, TDS is $8000 \mathrm{mg} / \mathrm{l}$, TSS is 7550 $\mathrm{mg} / \mathrm{l}$ and total solids is about $15550 \mathrm{mg} / \mathrm{l}$.
The physicochemical parameters investigated in this study showed that almost all the effluent characteristics were above the provisional discharge limit set by the Central Pollution Control Board (CPCB)

It is concluded that the Aloevera leaves used as natural coagulant for the treatment of tannery Industrial effluent. It was found that the percentage of reduction are high for the optimal dosage of about $1.5 \mathrm{~g} / \mathrm{l}$. which shows reduction efficiency of physico-chemical parameters such as Turbidity, Chlorides, Hardness, TSS, TS and TDS.

The efficiency removal were about $86 \%, 87 \%$ and $88 \%$ for Turbidity, TDS, Ts and TSS whereas the removal efficiency of Chlorides and Hardness was found to be $75 \%$ and $77 \%$. This study also conducted the optimization of various process parameters such as $\mathrm{pH}$, Coagulant dosage and contact time.

\section{ACKNOWLEDGEMENT}

We the author would like to thank E.K.M. leather industry which is situated at Erode district and the Principal, Government College of Technology, Coimbatore, for providing necessary facilities and guidance for our research work

\section{REFERENCE}

[1] Saravanan J et al (2017) "Wastewater Treatment using Natural Coagulant" International journal of Civil Engineering, (Pg.40-42)

[2] Shahida Parveen et al (2017) "Assessment of PhysicoChemical Properties of Tannery Waste Water and Its Impact on Fresh Water Quality" International Journal of Current Microbiology and Applied Sciences pp. 18791887.

[3] Manjushree Chowdhury et al (2015) "Characterization of the Effluents from Leather Processing Industries" Environ. Process (Pg.173-187).

[4] S. Ravi et al (2011) "Spectroscopy Studies on the Status of Aloin in Aloe vera". Journal of Experimental Sciences, (Pg.10-13)

[5] Gaikwad V. T. et al (2019) "Turbidity removal by conventional and ballasted coagulation with natural coagulant" Applied Water Science 9:130.

[6] Farid Ahmed et al (2018) "Adsorption of chromium from tannery wastewater with low-cost spent tea leaves adsorbent" Applied Water Science 8:129

[7] Korshin (2000) "Monitoring the properties of natural organic matter through UV spectroscopy : A Consistent Theory” Wat. Res. Vol. 31, No. 7, pp. 1787-1795

[8] Sessou Philippe et al (2016) "Evaluation of Aloevera leaf gel as a natural floculant" Research Journal of Recent Sciences (Pg 9-15) 
[9] Yudith Choque-Quispe II et al (2018) "Capacity flocculants natural coagulants in water treatment" Research Gate. (Pg 298-309)

[10] Fersi C (2018) "Characterizing the performance of coagulant - Flocculation of natural coagulant as pretreatment of tannery wastewater" (pp. 2379 - 2386).

[11] Keerthi Gowda BS (2017) "Application of natural coagulant in removal of turbidity" Research Gate. ISBN: 978-93-5267-355-1

[12] Mabu Sayid Mia M et al (2017) "BOD reduction using spent tea waste from tannery wastewater" J Sci Innov Res JSIR.

[13] Rajendran R. et al (2013) "Natural Coagulant Alternative to conventional methods of Water Purification", ISSN: 2277-8713, Vol.2 (1): (Pg.306-314).

[14] Prasad S.V.M. et al (2013) "Environmental Sciences-A Low Cost Water Treatment by Using Natural Coagulant", International Journal of Research in Engineering and Technology, ISSN: 2319-1163,Volume: 02 Issue 10.

[15] Nand V et al (2012) "Water Purification using Moringa Oleifera and Other Locally Available Seeds in Fiji for Heavy Metal Removal", International Journal of Applied Science and Technology Vol. 2 No. 5. 